\title{
PREDIKSI ANALITIK SUHU SOLAR ARRAY SATELIT
}

\author{
Ahmad Fauzi ${ }^{*}$ \\ Pusat Teknologi Satelit - LAPAN \\ Jl. Cagak Satelit Km.04 Rancabungur-Bogor 16310 \\ ${ }^{*}$ E-mail: fauzi7557@gmail.com
}

\begin{abstract}
Abstrak
Tujuan utama dari penggunaan coating paint pada sistem kendali termal satelit adalah menjaga semua elemen sistem satelit sesuai dengan batasan suhu operasional satelit. Panel surya sebagai sub sistem daya satelit berfungsi menyediakan daya yang dibutuhkan untuk operasional satelit yang disimpan dalam baterai setelah melalui perubahan energi, dari energi matahari ke bentuk energi listrik yang tersimpan dalam baterai. Energi yang tersimpan dalam baterai merupakan sumber daya satelit yang digunakan saat satelit dalam kondisi eclipse. Makalah ini membahas pemilihan finishing permukaan array surya satelit dari empat jenis yang ada dengan analisa penggunaan tiga buah coating paint dengan optical properties untuk sisi belakang array surya. Solar reflector dengan menggunakan coating white paint SG 121-FD dipilih sebagai finishing permukaan array surya desain daya termal satelit karena mempunyai nilai emissivitas yang tinggi dan nilai absorptivitas yang rendah.
\end{abstract}

Kata kunci: Termal, coatings, satelit, array surya

\begin{abstract}
The main purpose of coating paint on a thermal control system is to maintain all elements system in accordance with the operational temperature limit of the satellite. As parts os a power supply sub-system provide energy that allows for satellite operations that can be used in energy batteries stored in batteries. The energy stored in the battery is a resource that is currently in an eclipse condition. This paper discusses the selection of solar surface layers of the two existing types using three layers of paint with optical properties for the solar array side. Solar reflector using SG 121-FD white paint coating was chosen as the surface finishing array of thermal power design because it has a high emissivity value and low absorptivity value.
\end{abstract}

Keywords: Thermal, coatings, satellite, panel surya

\section{Pendahuluan}

Desain termal suatu sistem satelit adalah menjaga batasan suhu komponen sesuai dengan batasan yang diijinkan. Sistem kendali termal pada satelit yang menggunakan bahan coating paint biasanya adalah sistem termal pasif [1]. Penggunaan sistem termal pasif pada satelit banyak digunakan dalam berbagai aplikasi seperti penelitian yang dilakukan oleh Felipe dkk [2] yang memaparkan menggunakan MLI (multilayer insulation) dan radiator, paints, dan surface finishes untuk menjaga batasan suhu pada komponen satelit Amazonia-1. Micthao dkk [3] yang melakukan penelitian tentang desain termal menggunakan Matlab dengan mempertimbangkan kombinasi dari absorptivitas dan emisivitas infrared panel permukaan satelit, dimana analisa suhu panas dan dingin dengan perkiraan sudut orbit dan sudut jarak bumi dari matahari. Tan dkk [4] yang melaporkan distribusi suhu rata rata maksimum dan minimum solar panel yang diukur dari pusat solar panel menggunakan metode Kipp \& Zonen CMP3 pyranometer dan Data Logger Meteon. Sozbir dkk [5] melakukan penelitian tentang kendali termal pasif yang tersusun dari beberapa jenis bahan seperti heat pipe, MLI, radiator, paint dan surface finishes untuk menjaga batasan suhu komponen satelit sesuai dengan batasan suhu yang diijinkan, dan analisa kendali termal dilakukan dengan metode model matematika termal. Nazari dkk [6] mempelajari penggunaan termal pasif pada satelit observasi yang menekankan pentingnya pemilihan surface material dengan menggunakan sistem bahan insulasi seperti MLI. Andre G. C. Guerra dkk [7] melakukan penelitian analisa penggunaan dan pengujian komponen elektronik satelit terhadap lingkungan antariksa yang berkondisi suhu maksimum dan suhu minimum dengan sistem kendali termal pasif.. Berbagai desain yang mereka lakukan memerlukan keakuratan 
analisa termal lebih lanjut. Bahan coating digunakan untuk melindungi komponen satelit dari bahaya radiasi lingkungan ekstrim antariksa seperti radiasi sinar matahari. Satelit terdiri dari beberapa sub sistem dan salah satunya adalah sub sistem daya. Sub sistem daya sebagai bagian dari sistem engineering satelit, juga memerlukan analisa lanjut yang terkait dengan array surya yang digunakan. Dimana array surya merupakan sumber energi yang dibutuhkan oleh satelit. Energi yang dihasilkan oleh array surya akan disimpan dalam baterai satelit sebagai sumber energi utama yang menggerakkan satelit di orbit. Untuk memaksimalkan kinerja dan daya satelit perlu diperhitungkan atau diprediksikan jenis array surya dari sisi surface finishing-nya. Menurut Kim [8] pada umumnya ada 4 tipe ideal surface finishing array surya satelit sebagai desain termal array surya, yaitu pertama, solar reflector yang mempunyai emissivity tinggi dan nilai absorptivity yang rendah. Kedua, flat absorber yang mempunyai nilai emissivitas dan absorptivitas yang tinggi. Ketiga, solar absorber yang mempunyai emissivitas yang rendah dan nilai absorptivitas yang tinggi, dan keempat adalah flat reflector yang mempunyai emissivitas dan nilai absorptivitas yang rendah, secara kartesian dapat digambarkan seperti pada Gambar.1.

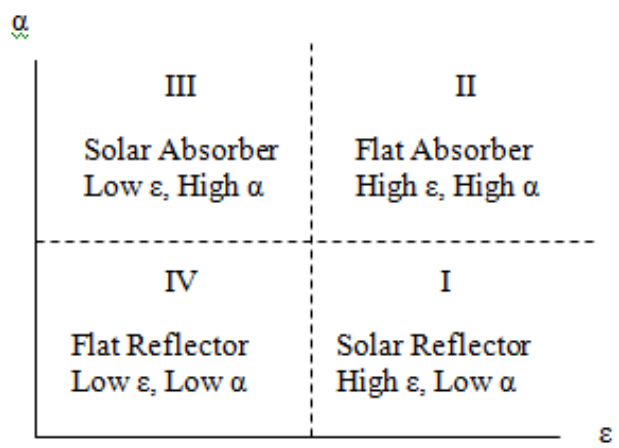

\section{Gambar 1. Grafik kartesian ideal surface finishing array surya [8]}

Dari ke-empat tipe surface finishing array surya tersebut, jenis solar reflector merupakan jenis ideal surface finishing yang paling banyak digunakan pada analisa termal array surya satelit, karena sesuai dengan batasan suhu termal yang dipersyaratkan dalam desain analisis suhu array surya. Selain itu juga suhu ekstrim lingkungan angkasa di orbit sangat mempengaruhi besarnya efisiensi array surya. Pada makalah ini pendekatan secara analytical dilakukan untuk mengetahui besarnya suhu array surya yang terjadi pada satelit dari analisis suhu panas maksimum (worst hot case) dan suhu dingin minimum (worst cold case) dengan memperhatikan jenis penggunaan coating paint pada satelit.

Pendekatan yang digunakan dalam analisa termal surface finishing array surya adalah pendekatan secara analitik dengan memperhatikan kondisi orbit satelit, yaitu ketinggian orbit dengan struktur tetap, solar array yang membentang (deployeable). Satelit ketika beredar mengelilingi bumi, ada saat waktu dimana bagian permukaan depan panel surya menghadap sinar matahari langsung sehingga mengalami degradasi panas yang berasal dari lingkungan antariksa khususnya sinar matahari atau yang dinamakan kondisi daylight. Sedangkan ketika panel surya satelit berada di daerah bayang-bayang bumi sehingga tidak terkena sinar matahari, keadaan ini disebut eclipse.

\section{PERSAMAAN ENERGI}

Sebagai ilustrasi pembelajaran dari sub sistem satelit tentang distribusi suhu, dibutuhkan penyelesaian energi steady-state. Karena termal seluruh sistem satelit saling terhubung satu sama lain, maka perlu sebuah sistem persamaan yang dapat menyelesaikan distribusi suhu dari tiap sub sistem. Untuk persamaan solar array satelit dengan posisi membentang, dapat dianalisa besaran suhu array surya yang menghadap matahari dan suhu pada sisi belakang array surya yang membelakangi sinar matahari seperti pada persamaan. 1 [8].

$m C_{p} \frac{d T}{d t}=q_{\text {cell }}+q_{\text {back }}-\sigma \varepsilon_{\text {cell }} \alpha\left(T_{S A}^{4}-T_{\text {space }}^{4}\right)-\sigma \varepsilon_{\text {back }} \alpha\left(T_{S A}^{4}-T_{\text {space }}^{4}\right)$

$0=q_{\text {cell }}+q_{\text {back }}-\sigma \varepsilon_{\text {cell }} \alpha T_{S A}^{4}-\sigma \varepsilon_{\text {back }} \alpha T_{\text {sa }}^{4}$

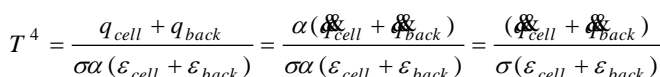

Dimana simbol yang digunakan dalam persamaan 1 diatas adalah seperti yang dijelaskan pada [8], dan dengan runut persamaan 1 diatas, dapat diturunkan dengan memperhatikan hukum kesetimbangan energi yaitu energi yang masuk sama dengan energi yang dikeluarkan, serta dengan memperhatikan parameter nilai dari emisivitas, ( $\varepsilon_{\text {cell }}$ dan $\left.\varepsilon_{\text {back }}\right)$ dan absortivitas $\left(\alpha_{\text {cell }}\right.$ dan $\left.\alpha_{\text {back }}\right)$ solar array, sehingga didapatkan persamaan untuk suhu panas maksimum (daylight condition) dan suhu dingin minimum (eclipse condition) seperti yang diberikan pada persamaan 2 [8].

$$
\begin{aligned}
& T_{\text {Eclipse }}=\sqrt[4]{\frac{\left.\varepsilon_{\text {back }} \text { arthIR }_{\text {arl }}+\varepsilon_{\text {back }}\right)}{\sigma\left(\varepsilon_{\text {cel }}\right)}}
\end{aligned}
$$

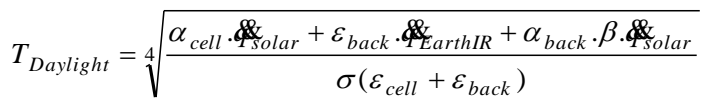

Ketika satelit beredar mencapai pada suatu ketinggian orbitnya, maka deretan panel surya akan terbentang. Ketika satelit beredar mengelilingi bumi ada saatnya satelit mengalami degradasi suhu pada panel suryanya yang dipengaruhi oleh faktor lingkungan eksternal (radiasi matahari, radiasi albedo bumi dan radiasi infrared bumi) dan faktor yang sangat dominan yaitu radiasi sinar matahari rata-rata sekitar $1367 \mathrm{~W} / \mathrm{m}^{2}$. Tapi juga dapat 
mencapai antara $1322 \mathrm{~W} / \mathrm{m}^{2}$ sampai $1418 \mathrm{~W} / \mathrm{m}^{2}$ tergantung pada waktu dan siklus perputaran matahari [9]. Satelit ketika pada posisi menghadap matahari (daylight) dinamakan posisi sun pointing, sedangkan ketika satelit berada pada bayang-bayang bumi (eclipse) dinamakan posisi nadir pointing, seperti yang diberikan pada Gambar.2.

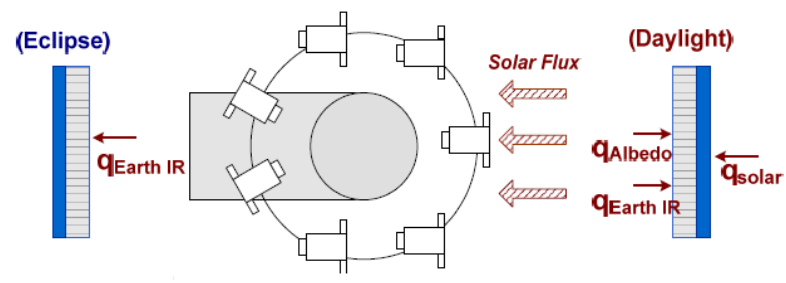

Gambar 2. Posisi sun pointing dan nadir pointing pada ketinggian orbit satelit $[8]$

\section{Array surya satelit}

Array surya atau solar array satelit merupakan struktur panel surya yang terdiri dari deretan sel-sel surya yang menghasilkan sumber energi dari matahari yang disimpan dalam baterai. Panel surya akan membentang ketika satelit berada di orbitnya dan akan mengarah ke matahari karena dilengkapi sensor cahaya. Saat tidak menerima cahaya matahari, satelit menggunakan baterai untuk menjaga fungsi sistem tetap berjalan sampai panel surya berfungsi kembali. Baterai tersebut diisi ulang menggunakan energi listrik dari panel surya [10]. Pada studi kasus pembelajaran ini, satelit yang menjadi analisa solar array adalah satelit KOMPSAT-3 milik KARI dengan struktur satelit pada Gambar.3.

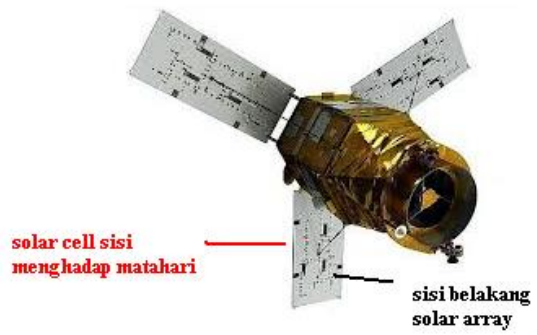

Gambar 3. Penampang solar array deployable [8]

Pemilihan jenis bahan thermo optical properties array surya pada desain suatu satelit perlu diperhatikan untuk mendapatkan daya satelit secara maksimum agar dapat memenuhi kebutuhan daya seluruh sub sistem satelit dan memperpanjang umur satelit. Pada studi ini akan dianalisa penggunaan jenis bahan coating array surya satelit dalam keadaan worse hot case dan worse cold case dengan data parameter lingkungan termal dan data optical properties yang digunakan seperti pada Tabel.1 dan Tabel 2.
Table 1. Data asumsi parameter lingkungan termal [11]

\begin{tabular}{ccccc}
\hline Kondisi & $\begin{array}{c}\text { Beta } \\
\text { angle, } \boldsymbol{\beta}\end{array}$ & $\begin{array}{c}\text { Flux } \\
\text { matahari, } \\
\mathbf{G s}\left(\mathbf{W} / \mathbf{m}^{2}\right)\end{array}$ & $\begin{array}{c}\text { Energi } \\
\text { infrared } \\
\text { bumi, } \\
\mathbf{q}_{\text {Earthl }} \\
\left(\mathbf{W} / \mathbf{m}^{2}\right)\end{array}$ & Albedo, a \\
\hline Daylight & 23 & 1418 & 258 & 0.35 \\
Eclipse & 0 & 1322 & 216 & 0.25 \\
\hline
\end{tabular}

Table 2. Optical properties penampang solar array [1][8]

\begin{tabular}{|c|c|c|}
\hline Optical properties & Emissivitas, $\varepsilon$ & $\begin{array}{c}\text { Solar } \\
\text { absorptivitas, } \sigma\end{array}$ \\
\hline Solar cell & $\begin{array}{c}0.899 \\
\text { Sisi belakang solar array }\end{array}$ & 0.92 \\
\hline $\begin{array}{l}\text { White paint SG 121- } \\
\text { FD }\end{array}$ & 0.88 & 0.39 \\
\hline $\begin{array}{l}\text { White paint A276 } \\
\text { Chemglaze }\end{array}$ & 0.28 & 0.88 \\
\hline $\begin{array}{l}\text { Ceramic white paint } \\
\text { AZW-11 LA }\end{array}$ & 0.10 & 0.91 \\
\hline Solar reflector (ideal) & 0.99 & 0.01 \\
\hline
\end{tabular}

White paint SG 121-FD [12] merupakan jenis coating yang pernah digunakan oleh satelit SPOT5 milik CNES (Badan Antariksa Perancis), yang diluncurkan pada tahun 2002 dengan orbit sun synchronous pada ketinggian orbit $820 \mathrm{~km}$. Coating jenis ini digunakan karena mempunyai efek yang melindungi satelit dari lingkungan ekstrim orbit satelit di angkasa. Selain itu jenis bahan coatings ini juga mempunyai kestabilan dan sensitivitas terhadap AO (atomic oxigen) dari sinar matahari, dan penelitian inipun pernah dilakukan kajian efek dari AO terhadap benturan material satelit orbit rendah (LEO, Low Earth Orbit) dengan kecepatan $8 \mathrm{~km} /$ detik [8].

\section{Metode}

Metode yang digunakan sangat sederhana untuk mempermudah proses penghitungan suhu, maka digunakan Microsoft Excel, diawali dengan memasukan data thermo optical properties dan data parameter lingkungan termal satelit, sehingga dihasilkan keluaran data berupa nilai/besaran suhu menggunakan rumus yang diberikan pada persamaan.2. Data keluaran tersebut digunakan sebagai referensi desain. Alur metode yang digunakan seperti pada Gambar.4. 


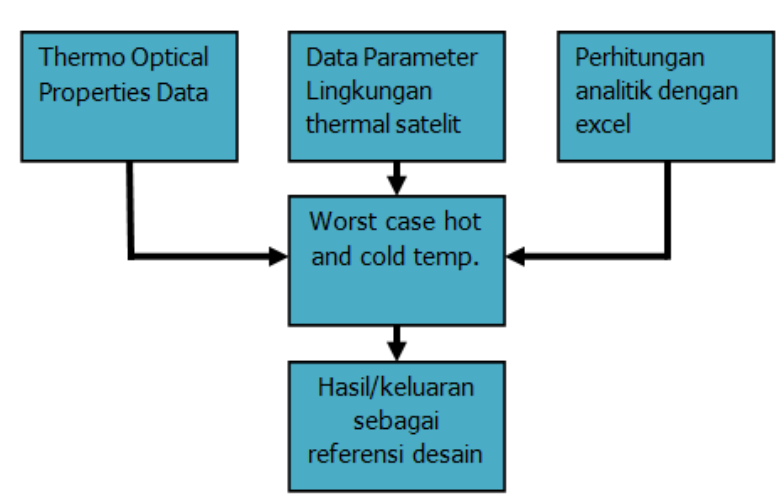

Gambar 4. Metode yang digunakan

\section{Hasil dan Analisa}

Penggunaan dan pemilihan jenis bahan material optical properties sangat menentukan jenis kendali desain termal yang digunakan, baik metode sistem kendali termal pasif maupun sistem kendali termal aktif. Pada umumnya satelit dengan sistem kendali termal pasif menggunakan bahan coating paint yang mempunyai nilai emissivitas yang tinggi untuk menghilangkan beban panas yang lebih pada radiator satelit, MLI yang digunakan untuk meminimalisasi radiasi panas yang hilang dari satelit dan menjaga komponen satelit dari suhu dingin minimum selama eclipse, dan radiator yang mengendalikan radiasi sisa panas yang dibuang keluar ke angkasa, dimana permukaan radiator pada umumnya mempunyai absorptivitas yang rendah dan emissivitas yang tinggi.
Ketiga faktor tersebut sebagai desain termal yang didesain pada studi kasus ini, karena mudah, sederhana dan handal [1][11].

Penggunaan bahan coating paint sendiri berguna untuk melindungi baik struktur maupun komponen-komponen satelit dari cuaca antariksa yang ekstrim. Analisa array surya ini dilakukan pada tiga jenis bahan material seperti yang diberikan pada Tabel.2 dengan menggunakan data parameter data lingkungan termal yang diberikan pada Tabel.1, maka pendekatan secara analytical dilakukan untuk menentukan desain termal, khususnya suhu daylight dan suhu eclipse satelit dari sisi belakang array surya. Dengan menggunakan persamaan 2 didapatkan hasil besarnya suhu panas maksimum dan suhu dingin minimum satelit dari ketiga jenis bahan coating yang digunakan seperti pada Tabel.3.

Pada grafik Gambar.5 dapat dilihat bahwa suhu maksimum ekstrim yang terjadi saat kondisi satelit mengalami degradasi panas ketika permukaan sisi array surya satelit secara maksimum menghadap matahari yang terjadi pada suhu sebesar $143.4^{\circ} \mathrm{C}$ dan mengalami pendinginan yang terjadi saat satelit berada dibayangbayang bumi atau eclipse pada suhu terdingin sebesar $-67.8^{\circ} \mathrm{C}$.

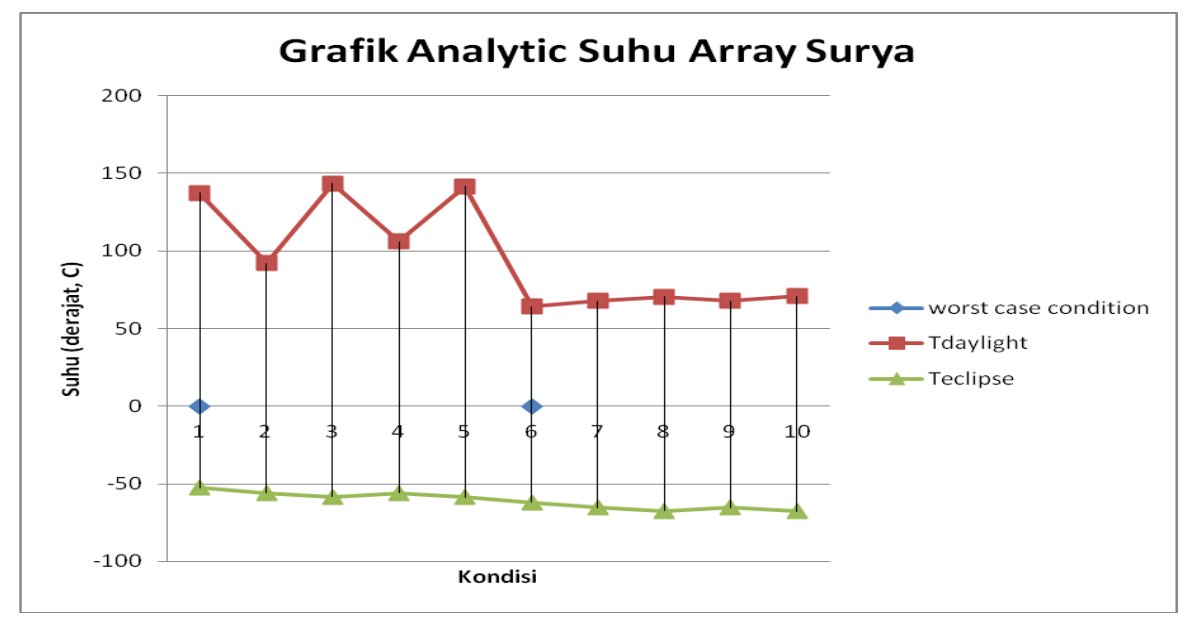

Gambar 5. Grafik suhu array surya dengan pendekatan secara analytical

Table 3. Hasil perhitungan analytical

\begin{tabular}{lcccc}
\hline \multirow{2}{*}{ Jenis coatings } & \multicolumn{2}{c}{ Worst hot case } & \multicolumn{2}{c}{ Worst cold case } \\
\cline { 2 - 5 } & Tdaylight $\left({ }^{\circ} \mathrm{C}\right)$ & Teclipse $\left({ }^{\circ} \mathrm{C}\right)$ & Tdaylight $\left({ }^{\circ} \mathrm{C}\right)$ & Teclipse $\left({ }^{\circ} \mathrm{C}\right)$ \\
\hline White paint SG 121-FD & 84.6 & -58.6 & 65.4 & -67.9 \\
White paint A276 & 90.7 & -112 & 57.3 & -119 \\
Chemglaze & & -148.6 & 54.7 & -154 \\
Ceramic white AZW-11 LA & 89.3 & & \\
\hline
\end{tabular}




\section{Kesimpulan}

Analisa dengan pendekatan analitik yang dilakukan menggunakan perpaduan solar reflector dan termo optical properties bahan coating white paint SG 121-FD pada solar array memperlihatkan bahwa dengan nilai emisivitas yang tinggi dan solar absorptivitas yang rendah dapat mengurangi degradasi lingkungan antariksa ekstrim terhadap satelit karena dapat menekan besaran suhu panas maksimum sebesar $84.6^{\circ} \mathrm{C}$ dan suhu dingin minimum sebesar $-67.9^{\circ} \mathrm{C}$, dan menjadi pertimbangan untuk digunakan dalam studi kasus ini.

\section{Referensi}

[1]. Anvari, A., Farhani, F., Niaki, K S. Comparative Study on Space Qualified Paints Used for Thermal Contro of a Small Satellite. Iranian Journal of Chemical Engineering. 2009. 6(2), 50-62

[2]. Felipe, D., Muraoka, I., Garcia, E. Thermal Control Design Conception of the Amazonia-1 Satellite. Journal Technology Management. 2014. 6(2), 169 - 179.

[3]. Mitchao, D.P., Totani, T., Wakita, M., Nagata, H. Preliminary Thermal Design for Microsatellites Deployed from International Space Station's Kibo Module. Journal of Thermophysics and Heat Transfer. 2018. 32(3), 789 - 798.

[4]. Tan, N., Wei, J., Nan, W., et al. Experimental Study of Efficiency of Solar Panel by Phase Change Material Cooling. International Conference on Materials Technology and Energy. 2017. IOP Conf. Series: Materials Science and Engineering 217 012011, (pp. 1 $6)$.
[5]. Sozbir, N., Bulut, M., Oktem, M F., Kahriman, A., Chaix, A. Design of Thermal Control Subsystem for TUSAT Telecomminication Satellite. WASET International Journal of Computer and Systems Engineering. 2008. 2(7), $1370-1373$.

[6]. Nazari, A., Emami, H. Thermal Control and Thermal Sensors of Observation Satellite. The International Archives of the Photogrammetry, Remote Sensing and Spatial Information Sciences. 2008. Vol. XXXVII. Part B2, 949 - 952.

[7]. Andre G. C. Guerra, Diego Nodar-Lopez, Ricardo TuboPardavila. (2018). Thermal analysis of the electronics of a CubeSat mission. Preprint submitted to Applied Thermal Engineering.

[8]. Kim, Hui-kyung., Lee, Jang-Joon. Thermal Design of The Solar Array in a Low Earth Orbit Satellite by Analytical and Numerical Methods. 10 December 2018

[9]. Clawson, J.F., Tsuyuki, G.T., Anderson, B.J., Justus, C.G., Batts, W., Ferguson, D., et al. Spacecraft Thermal Environment. In D.G Gilmore (Ed), Spacecraft Thermal Control Handbook. Vol.I: Fundamental Technologies. El Segundo, CA: The Aerospace Press. 2002.

[10]. Fadly, R. Manfaat Panel Surya Sebagai Pembangkit Listrik Tenaga Matahari. 4 June 2014.

[11]. Gilmore, D.G. Spacecraft Thermal Control Handbook Vol.I. Fundamental Technologies. The Aerospace Corporation Press. 2002.

[12]. Nabarra, P., Bellouard, E., D'Escrivan, S. (2011). Inflight aging of thermal coatings on therme experiment. Journal of Spacecraft and Rockets. 2011. 48(1), 27 - 33. 